\title{
Legal Protection toward Outsourcing Workers Connected with Indonesian Employment Law
}

\author{
Isni Rubiantini \\ Sekolah Tinggi Hukum Bandung \\ Bandung, Indonesia \\ isnirubiantini_bu@yahoo.com
}

\begin{abstract}
The purpose of this research is to know the legal protection of outsourced workers by identifying the responsibilities of service and service provider companies against the rights and obligations of outsourced workers who are harmed and want to know the legal protections for outsourced workers related to labor laws in Indonesia. This research is analytical descriptive method used normative juridical approach. The data of this study include labor legislation related to employment. The results showed that the form of protection against outsourced workers is done by making cooperation agreements and employment agreements so that the rights and obligations of workers are not harmed. This indicates that there is no direct legal relationship between outsourced workers and employers because work agreements are made between workers and employers' services companies. The legal relationship exists between the employer company and the employer's service company, but the employee must also comply with the applicable Company Rules in the employer company. While the second problem is the legal protection of outsourced workers have not fully obtained by the workers because in general they are just workers / contracts so that the welfare given is also limited only as determined by the existing legislation-legislation.
\end{abstract}

\section{Keywords-legal protection; employment; outsourcing}

\section{INTRODUCTION}

In accordance with the mandate of the 1945 Constitution of the State of the Republic of Indonesia, every citizen is given equal standing before the law of both men and women to obtain their basic rights. In the field of manpower stated in Article 27 paragraph (2) of the 1945 Constitution that "Every citizen shall have the right to work and a livelihood worthy of humanity". The meaning of such basic rights shall be the right to obtain a position in law and justice, decent work and livelihood, acquire education, union and assembly, issue of opinions and thoughts, including the right to choose professions, promotions, and training to achieve certain achievements without differentiating between men and women.

Many companies are now recruiting their workforce through a service provider company or better known as outsourcing, companies that use outsourcing services are rising so high that even the word "outsourcing" seems familiar to our ears. However, there are still many prospective workers who do not understand correctly, what exactly works with outsourcing system [1].
These outsourcing workers do not have much choices as unemployment is open nationwide. Meanwhile, many companies are closed because they are unable to compete with imported products, while export products also decline due to high production costs in the country. Outsourcing in Indonesia, still regarded as a concept strategy, has not been used as a tool or means aimed at reducing unemployment and increasing foreign exchange for the country.

Activities that can be outsourced are supportive activities, or non-core activities or business, while the main business remains self-administered. Often it is rather difficult to tell the difference. To be able to distinguish, it is actually the most helpful thing is to know what the main results of the company. The last major process that produces the main results of the company can be called the core business.

Under Law No. 13 of 2003 on Employment requires that an outsourcing agreement be a written agreement, which in this article is referred to as a charter agreement [2]. Job requirements that can be submitted to outsourcing, namely:

- It is done separately from the main activities;

- It is carried out by direct or indirect orders from employers, c.

- It is the company's overall support activities; and;

- It is not hampering the production process directly.

The purpose of outsourcing is directed to improve business concentration on core activities, not always addressed honestly by business actors. Often outsourcing deviates from its original purpose and only serves as a tool to save company spending on wage workers and eliminate the created because of its concentration split on labor issues. Risk or anything that is imposed on the company with regard to workers' welfare.

Basically, outsourcing has an orientation on the relationship between the service user company, the service provider company and the worker, with the outsourcing of the service user company can concentrate on the core activities of its business in order to increase production and face market competition.

The work relationship through outsourcing mechanisms have mushroomed in Indonesia. Almost most companies use outsourcing strategy I $n$ the implementation of their business 
activities. Working relationships through outsourcing mechanisms are more harmful and tend to benefit one party, in this case the service user. Service user companies get low-cost workers and a light risk burden by applying an outsourcing strategy. The service user company should not be preoccupied with the selection of workers, even further in the event of a dispute between the user of the service and the worker is not the responsibility of the service user company but the responsibility of the service provider company of the worker/laborer or the worker himself. Employers' services providers must bear the risk of disputes between employers and employed workers, who until now have not reached an agreement/solution expected by all parties. Thus, outsourcing in reality will make industrial relation unclear.

The provision on outsourcing in Article 66 of Law Number 13 Year 2003 on Manpower, on the one hand has opened up the possibility of emerging new companies engaged in services, and on the other hand has enabled companies that have stood for efficiency through utilization service outsourcing company to produce certain products or services that are not directly related to the main business of the company [3].

The provision of outsourcing in Article 66 of Law Number 13 Year 2003 on Manpower, on the one hand has opened up the possibility of emerging new companies engaged in services, and on the other hand has enabled companies that have stood for efficiency through utilization service outsourcing company to produce certain products or services that are not directly related to the main business of the company [4].

Tourism in Bali is developed in order to encourage economic activity and enhance the image of Indonesia, improve the welfare of local communities, and provide expansion of employment opportunities. The development of tourism utilizes the diversity of natural beauty charms and national potentials as the largest marine tourism area in the world wisely and sustainably, and encourages economic activities related to the development of the nation's culture. Hotel as one of the tourism facilities has a very big role to the development of tourism and provide employment opportunities. The security unit is the supporting worker has contributed much to the economic progress in general. In Hotels in Kuta, Bali, most of the security guard workers as outsourced workers, employment relationship occur based on certain time labor agreement between workers and service providers.

Some of the problems that can arise in outsourcing work relationships are on accountability for unlawful acts committed by the parties, for example: a violation of work discipline, criminal offense, abuse of user service company facilities performed by workers, service user companies in the implementation of providing employment in beyond the agreed limit or the execution of overtime hours not in accordance with the employment agreement. Service provider companies are responsible for wages, holiday allowances, social security of labor and the provision of work equipment. Some outsourcing companies do not provide protection against the rights of outsourced workers so that employers must provide better protection in accordance with the applicable laws and regulations [5].

Outsourcing workers need to be given legal protection for the reason of saving a very potential workforce and for general economic progress. Most of these outsourced workers are professionals in their field, young in age, and have high morale. Their shortcomings are mostly because it is not with the company's policy makers. This potential workforce needs to be protected on the grounds that when the nation's economic development movement begins to run again these workers remain available and ready to welcome the post-crisis economic rebuilding of Indonesia.

\section{METHOD}

\section{A. Research Specification}

This research is done by analytical descriptive method that gives description of applicable regulation related to legal theories and practice of law and practice of implementation of positive law concerning the problem above. In general, analyzing as much data as possible about the legal protection of outsourced workers is associated with Law Number 13 Year 2003 on Manpower.

\section{B. Approach Method}

The approach in this research is to use normative juridical approach method, which deductively begins the analysis of Law Number 13 Year 2003 on Manpower. This method of approach focuses on the science of law using bibliographic data and seeks to examine the rule of law as well as the rules of law applicable in society. Normative legal research is a literature research that is research on primary, secondary, and tertiary legal materials.

\section{Data Collection Techniques}

Performed on secondary data to obtain a theoretical basis in the form of opinions or writings of experts or other parties in the form of information either in the form of formal or through official texts.

\section{RESULT AND DISCUSSION}

The development of the global economy and rapid technological advances have had the impact of such tight competition taking place on all fronts. This highly competitive environment by the business world to adapt to market demands is a very fast and flexible response in improving customer service. Increasingly fierce market competition, companies increasingly focus on their own field of expertise, play their own profits, and focus on working with other companies, especially for small and medium-sized businesses. Outsourcing as an important strategy to take advantage of limited resources, reduce company costs and improve core capabilities of the company, has been much feared by the company.

In the last few years, outsourcing has been very much discussed by producers of goods and services, because outsourcing has been done deliberately to suppress workers with protection and working conditions far below what should 
be given so that it is very detrimental to workers. Such outsourcing can cause worker's unrest and is often followed by strike, so that the purpose of outsourcing as mentioned above is unachievable due to the disruption of the production process of goods and services.

Some hotel entrepreneurs who cooperate with service provider companies mostly in the implementation in accordance with applicable legislation. For example: the wages earned by workers are above the minimum wage of the district, safety and health of the highly paid attention in some service user companies, registered to the participants of Social Security Workforce, given overtime pay in accordance with the agreement with the service user company. One way to minimize problems in the field of outsourcing, then between workers, service providers companies and enterprise service users made an agreement. The agreement between the service user company and the service provider company is in the form of a cooperation agreement which becomes the reference of a certain time working agreement between the worker and the service provider company. It is the legal consequences of this Agreement that give rise to the rights and obligations of the parties.

Constitution Article 65 of Law Number 13 of 2003 on Manpower regulates the terms of the company that can provide the worker for the interests of the parties involved in the outsourcing agreement, whether the parties concerned or to the employed workers are not harmed, especially the outsourced workers who usually are in a weak position. In the implementation if the right of this worker is not obeyed by service user company or service provider company hence responsible is service provider company.

The implementation, if the service provider company does not instruct the worker to do the work in order to get the result of work according to the agreement, will result in the end of the cooperation agreement between the service user company and the service provider. So that workers will be disadvantaged because with the end of the cooperation agreement will end also work agreements between workers and service providers.

Implementation of outsourcing even though the parties involved are three parties, but because the work agreement is made, approved, and signed by two parties only the workers and the outsourcing company, then the employment relationship is only found in the workers and outsourcing companies only. This implies that outsourcing companies are employers of outsourced workers, so the legal consequences of employment, orders and wages should be provided by outsourcing companies.

In outsourcing employment relationship, the determination of work and work orders of the service user company and it is contained in the employment agreement. The employment relationship between the worker and the outsourcing company also contains the legal consequence that the relevant outsourcing company is the party responsible for providing work accident, sickness, or severance pay to the outsourced workers in the event of termination of the employment contract. Regarding the payment of wages shall be in accordance with the agreed upon in terms of the amount of wages and time of payment, as well as overtime pay and benefits.

The responsibility of the service user company with the existence of an employment agreement on the execution of outsourcing is that the service user company shall respect and also comply with the provisions contained in the work agreement between the outsourced worker and the relevant outsourcing company that is the rights and obligations of the outsourced worker, among other things: allowing the worker to leave, allowing unemployment for a sick worker with a certificate, allowing for non-employment for workers who will undertake religious ceremonies, observe and evaluate the work of the worker, and may give warning if the worker that work is not in accordance with the standards of work in the enterprise service users.

The forms of work relationship scheme occurring in outsourcing activities are as follows can see in fig. 1:

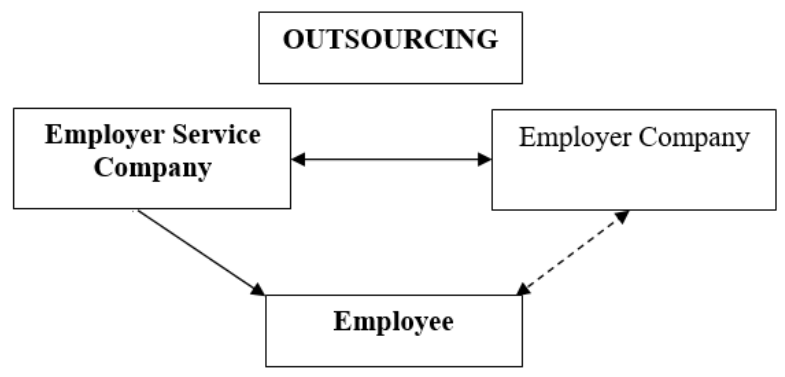

Fig. 1. The forms of work relationship scheme occuring in outsourcing activities.

Work relationship that occur in outsourcing are between workers / laborers and employers' service companies and poured in Written Work Agreement. This can be seen from the scheme above that there is direct relationship between workers with service provider companies. Looking at the relationship of the triangle, i.e., between employers, workers, and service companies, there has been a shift in the definition of working relationships. In an ordinary employment relationship the worker has a direct relationship with the employer who hires it and the employer will pay all the rights of the workers directly as well, and vice versa, the worker will give his power directly to the company who recruited him. This does not apply to outsourced employment relationships, where payments are made through employers to employers and employers to employees [3].

The role of the government in providing legal protection to workers is very great, the government conducts supervision to the parties that implement outsourcing. This is evident in Article 176 of Law Number 13 of 2003 concerning Manpower in which regulates the implementation of labor inspection conducted by competent and independent labor inspectors to ensure the practice of outsourcing in Indonesia [2].

Decision of the Constitutional Court in its decision Number 27/PUU-IX/2011 and Elucidation of Article 66 paragraph (2) part (c) UUK, workers employed by outsourcing companies in accordance with the employment agreement, company regulations or collective labor agreements, equal to the 
protection of wages and welfare, terms of employment, and disputes arising, with workers in employer companies. Thus, workers working in a service-using company through an outsourcing company are entitled to the same wages and wages as those employed by service companies that do not go through outsourcing companies. Such wage and welfare protection shall be included or contained in the employment agreement between the worker and the outsourcing company. If it is not contained in the employment agreement, such protection refers to company regulations or collective labor agreements. Where in company regulations or collective bargaining agreements are also not regulated, wage and welfare protection refers to the provisions set forth in the prevailing laws and regulations [5].

Every worker is entitled to income that meets a decent livelihood for humanity in order to realize a decent livelihood income, the government sets wage policies that protect workers by paying attention to productivity and economic growth. Article 89 of Law Number 13 Year 2003 concerning Manpower provides that workers receive wages based on provincial or district minimum wage [2].

Every worker/laborer and his/her family shall have the right to obtain social security of labor in accordance with article 99 of Law Number 13 of 2003 concerning employment [2]. Outsourced workers in the hotel sector in Bali are mostly included to participate in social worker insurance. For workers who have family members service companies in a cooperation agreement only able to provide workers to participate in social security of labor as single or unmarried workers so that workers' families do not have the right of accident insurance, death insurance, old age insurance and health care insurance this not in accordance with Article 6 of Law Number 13 Year 1992 regarding Social Security Workforce, only a few workers who are not participants of the social security, namely:

- Workers receive wages below the minimum wage.

- Requests from the workers themselves.

Thus, the assumption that the working relationship on outsourcing always use a certain time/contractual agreement that obscures industrial relations such as outsourcing company can easily not guarantee work welfare is not true because the implementation of outsourcing also pay attention to the workers involved in it as human beings with all the dignity and its dignity on the basis of a sense of justice and propriety in accordance with the values and the 1945 Constitution.

In addition to these efforts, to reduce the occurrence of confusion, can be done by creating and establishing the scheme of the production process of a good or service so that it can be determined the core business; beyond that means support work. In this case to equate perceptions need to be communicated with workers/laborers and unions and related agencies to be included in company regulations/collective labor agreements.

Basically, the main purpose of a company outsourcing is to improve the ability and competitive advantage of the company in order to survive and grow. Working agreement on the execution of outsourcing in the form of a certain time work agreement based on the period or completion of a particular job, this work agreement is made in writing. Agreement for a specified time may be made only for certain occupations which by type and nature or activity of its work shall be completed within a specified time pursuant to Article 59 of Law Number 13 of 2003 concerning employment. The applicable laws and regulations can also affect the legal protection of outsourced workers not only from employment agreements but also from corporate regulations and joint working regulations of both the outsourcing company and the service user.

Employment protection of the worker/laborer is an absolute necessity in the employment process, in accordance with the provisions on the Implementation of the Minister of Manpower and Transmigration No. KEP-101/MEN/IV/2004 concerning Procedure of Licensing of Worker/Service Provider Company. Any work the company obtains from other companies, then both parties must make a written agreement containing at least:

- The type of work that will be performed by the workers of the service provider company;

- The type of work the worker/laborer will be doing from a skilled company Ratification that in carrying out the work referred to in item a, the employment relationship is between the service provider company and the worker employed by the service provider company, so that the protection of wages and welfare, the terms of employment and disputes arising shall be the responsibility of the service provider company/previous laborers, for the types of work that is continuously in the employer company in the event of a replacement service provider company workers/service workers.

After the judicial review of Article 59 and Article 64 of the Constitutional Court Law, and subsequently resulting in the decision of the Constitutional Court Number 27/PUU-IX/2011, then the Circular Letter of the Director General of Industrial Relations and Social Security of Manpower of the Ministry of Manpower and Transmigration of RI (Republic of Indonesia) Number: B.31/PHIJSK/I/2012 on Implementation of Decision of Constitutional Court Number 27/PUU-IX/2011. Based on the Circular Letter relating to the legal considerations in the decision of the Constitutional Court Number 27/PUU-IX/2011, the working relationship between the Outsourcing Company and the worker/laborer may be made/contracted through a Working Agreement of Uncertain Time/Permanent Work or through a Specific Time Working Agreement/Contract. If the employment relationship is contracted to a specified employment agreement, the worker shall continue to enjoy protection of his or her rights as an employee by applying the Transfer of Undertaking Protection of Employment (TUPE) principle, in the event of a substitution of an employer or an outsourcing company [6].

In addition to the Manpower Law No. 13 of 2003, the government also issues implementing regulations governing the implementation of outsourcing in Indonesia [2]. Outsourcing arrangements in the Manpower Act and its implementing regulations are intended to provide legal certainty and at the same time provide welfare for workers/laborers. That in practice there are those that have not been properly implemented is a matter to be solved because it concerns the Industrial/Employment relationship for workers and employers/Companies. 


\section{CONCLUSION}

Relationship between employees and the service user company occurs based on cooperation agreement between service user company and service provider company. The employees are positioned in service provider company based on the contract with the service provider company and this agreement yield rights and obligation occurrence of the two parties. Service user and service provider companies are responsible for the fulfillment of the employees' rights in the relationship between service provider companies and the employees. Such responsibility must be written down in the work contract between service user company and service provider company. Both service provider company and service user company are responsible for the disadvantaged employees' rights and obligation.

Although Constitution in Number 13 of 2003 and the implementation rules have provided legal protection toward outsourcing workers, practically workers' welfare warranty is not given to outsourcing workers. Basically, due to their basedfixed schedule work, given welfare is always depended on the limitation of determined capacity in the available legislation.

\section{ACKNOWLEDGEMENT}

The author would like to thank all the parties who have helped and contributed in the writing of this article, both those who contribute in the form of funding and critical ideas. Hopefully this paper can be useful theoretically and practically for the addition and development of knowledge, especially in the field of legal science.

\section{REFERENCE}

[1] Kolahman Saragih, Doctoral Program of Law Science University of North Sumatera Medan, Indonesia, Jurnal Atlantis Press, Advances in Social Science, Education and Humanities Research (ASSEHR), volume 141 International Conference on Public Policy, Social Computing and Development 2017 (ICOPOSDev 2017).

[2] Article Number 13 of 2003 on Employment Law.

[3] S. Damanik, Outsourcing And Work Agreement, Cet II. DSS Publishing. Jakarta. 2007.

[4] A. M. T. Anggraini, "Kajian Yuridis Terhadap Perjanjian Penetapan Harga Berdasarkan Undang-Undang Nomor 5 Tahun 1999 tentang Larangan Praktik Monopoli dan Persaingan Usaha Tidak Sehat", Artikel, Sekar Trisakti, hlm. 15. 2011.

[5] Kadek Agus Sudiarawan, Legal Analysis On Outsourcing Implementation Of Corporate User Side Worker, Journal of Social Science and Humanities Vol.5. No.2. okt 2016

[6] Hukumonline.com.akses on january 24, 2018.jam 10.15 